\title{
How Do Private Family Firms Face the Crisis? Empirical Evidence from Belgium
}

\author{
Jonathan Bauweraerts ${ }^{1}$ \\ ${ }^{1}$ Warocqué School of Economics and Management, University of Mons, Mons, Belgium \\ Correspondence: Jonathan Bauweraerts, Warocqué School of Economics and Management, University of Mons, \\ Place Warocqué, 17, 7000, Mons, Belgium. Tel: 32-65-37-3276. E-mail: jonathan.bauweraerts@umons.ac.be
}

Received: May 13, 2013

Accepted: June 24, 2013

Online Published: July 26, 2013

doi:10.5539/ibr.v6n8p91

URL: http://dx.doi.org/10.5539/ibr.v6n8p91

\begin{abstract}
Whereas listed family firms have already received great attention concerning the effect of the crisis on performance, few studies focus on private family firms acting in a hostile environment. This paper tries to fill this gap by investigating how the financial and economic crises affect the relationship between family involvement and performance. This research is led on the Belgian market and based on panel data collected on the period 2002-2011. Multiple regression analysis and Heckman two-steps method show that private family firms exhibit greater performance during the crisis. These results seem to confirm that family involvement enhances potential of resilience in private firms so that they outperform their non-family peers during periods of crisis.
\end{abstract}

Keywords: family firms, family involvement, organisational resilience, performance

\section{Introduction}

Family firms receive an ample consideration in the literature since twenty years. Indeed, family firms have long been known as a sub-optimal organisation but their considerable weight in economy has created a relevant field for researchers (Ifera, 2003; Duh et al., 2009). Numerous researches have focused on the relationship between family ownership and performance. Nevertheless, even if family firms' outperformance seems to predominate in the literature (Charreaux, 1991; Coleman \& Carsky, 1999; Anderson \& Reeb, 2003; Andres, 2008; Bughin \& Colot, 2008; Ahmad \& Amran, 2010), neutral (Chrisman et al., 2004; Jaskiewics et al., 2006; Rutherford et al., 2008) and negative (Yurtoglu, 2000; Barth et al., 2005; Klein et al., 2005; Giovannini, 2010; Kowalewski et al., 2010) effects of family ownership on performance are also noticed.

Besides, companies have to cope with the financial and economic crisis since 2008. This special context creates an opportunity to analyse firms' performance in a hostile setting (Chrisman et al., 2011). Whereas this problematic has already been studied in previous research focusing on large listed firms (Lemmon \& Lins, 2003; Lins et al., 2011), this issue remains under-investigated in private family firms (Astrachan, 2010). This paper tries to fill this gap by analysing how the crisis affects the relationship between family involvement and performance.

In order to answer this interrogation, agency (Jensen \& Meckling, 1976) and socioemotional (Gomez-Mejia et al., 2007) perspectives as well as the frame of organisational resilience (Bloch et al., 2012) are developed and applied to private family firms. Indeed, limited agency costs due to the overlap of ownership and management (Jensen \& Meckling, 1976; Anderson \& Reeb, 2003) and the strong identification of family members and external stakeholders with the organisation (Gomez-Mejia et al., 2007) are likely to provide private family firms with a competitive advantage in order to cope with unexpected situations such as the sudden financial crisis.

This research is led on panel data collected over the period 2002-2011 on the Belgian market of private firms. Multiple regression analysis is used in order to determine how the crisis influences the relationship between family involvement and performance. Moreover, as endogeneity problems can appear when analysing the influence of ownership on performance (Demsetz \& Lehn, 1985; Demsetz \& Villalonga, 2001; Maury, 2006), Heckman two-steps method is used in order to mitigate reversed causality and auo-selection issues.

The structure of this paper contains several sections. A literature review analysing the relationship between family involvement and performance in a context of crisis is proposed in a first section. Methodology and results 
are illustrated in the subsequent sections. Finally, the conclusion, limitations and research perspectives are developed in a last section.

\section{Family Involvement, Performance, and the Crisis}

Family firm is the kind of organisation presenting the longest life expectancy throughout the world (Miller \& Le Breton-Miller, 2005). Some of them pursue their activity since the sixties although they had to cope with turbulences such as economic recession or political turmoil (Kenyon-Rouvinez \& Ward, 2004; James, 2006). Despite a statement of sustainability in family firms, the origins of their longevity are not well known. More specifically, their ability to deal with structural shocks stays under-investigated (Astrachan, 2010). An approach based on the concepts of High Reliability Organisation (Weick \& Roberts, 1993; Weick \& Sutcliffe, 2007) and organisational resilience (Bégin \& Chabaud, 2010; Chrisman et al., 2011) is relevant to create a theoretical frame explaining the relationship between family ownership and performance during the financial crisis.

Arrègle et al. (2007) underline that the family brings in the company several specifics inputs in terms of capital, labour, intellectual capacity, culture and trust. The combination of these factors would improve the decision-making processes and the functioning of the governance mechanisms implemented in the firm. Zahra et al. (2008) also indicate that the presence of the family stimulates the promotion of a strong culture valuing active participation. This family involvement is considered as an important driver of family firm's longevity and sustainability (Pieper, 2007). Moreover, as mentioned by Bloch et al., (2012), family firms manage the combination of entrepreneurship and sustainability orientations to meet the five criteria of high reliability organisation, namely failure obsession, simplification mistrust, operational sensitivity, will of survival and deference to expertise. The importance given to reliability in family firms confers them a capacity of adaptability and shock absorptions when they have to cope with exogenous shocks. In that respect, Bloch et al., (2012) find a positive and significant relationship between family ownership and firm's economic and financial performance during the financial crisis from 2008 as well as during the period of the Internet bubble explosion, indicating that family firms are more able to deal with a sudden event.

Moreover, by positioning under the agency perspective, the alignment of interests between owners and managers in family firms is an undeniable competitive advantage during a crisis period (Anderson \& Reeb, 2003). Indeed, the conflict of interest is more pronounced in non-family firms where the long term orientations from the owners and the short term motivations from the manager are more costly when a shock occurs. An example can illustrate this assumption. Managers have an undeniable incentive to invest in a risky project when the company is close to bankruptcy since they can take advantage of the excess of risk in such an operation without being penalised in the case of failure (Zhou, 2012). However, such a situation is more likely to occur during an economic crisis. Family firms where an overlap between majority owners and managers interests is usual do not meet that kind of problem. Villalonga and Amit (2006) show that family firms where the founder is still the CEO outperform other family firms. Besides, the financial crisis context contributes to a reinforcement of credit terms and conditions granted to companies as well as a decrease in the consumers' demand. These factors have an impact on the firm performance. Lins et al., (2011) note that the relationship between the presence of a blockholder and the firm valuation is exacerbated during a crisis period. Indeed, that kind of shareholder offers an easier access to internal and external funding (Wruck, 1989; Hertzel \& Smith, 1993; Stein, 1997), an asset on the product market (Kahnna \& Palepu, 2000) and a better control (Shleifer \& Vishny, 1997). Private family firms, characterised by the presence of a dominant family blockholder, benefit from these advantages when they face turbulences in the economic environment.

Outperformance of family firms during the crisis can also be explained by the fact that family owners usually want to preserve their socioemotional wealth (Gomez-Mejia et al., 2007). Indeed, due to their strong identification with the firm and willingness to pass a clean and sustainable company onto subsequent generations, family principals display greater concerns for family reputation and image (Berrone et al., 2012). In that sense, Chen et al. (2010) and Steijvers and Niskanen (2011) find that family firms are less tax aggressive than non-family firms, family owners preferring to preserve the image of the firm rather than to benefit from tax advantages which can induce administrative enquiries or penalties and therefore deterioration in firm reputation. This importance devoted to the confection of an unblemished reputation enables family firms to develop robust trade relationships with suppliers and customers. In a crisis period, this vector of organisational resilience leads family firms to manage gross sales margin in a more efficient way (Bloch et al., 2012).

Long-term orientations in family firms (Miller \& Le Breton-Miller, 2005), the importance given to the family firms reputation (Chen et al., 2010) in order to maintain good relationships with external stakeholders (Miller \& Le Breton-Miller, 2005), and the lower agency costs in this type of company (Anderson \& Reeb, 2003) enable to 
postulate:

H1: Family ownership is positively linked with firm performance in a context of economic turmoil.

\section{Methodology}

\subsection{Target Population and Sample}

Firstly, firms presenting an average number of permanent staff higher than 100 workers are collected in order to obtain all the financial information needed since these companies have to publish full-format accounts. After elimination of firms from financial and assurance sectors, the sample comprises 1.999 companies. Companies for which data are omitted or abnormal are eliminated from the sample. Each firm is then considered as a family business if it fulfils at least two of the following criteria:

- a family owned at least $50 \%$ of the firm's shares;

- a family has a decisive influence on corporate and transmission strategies. This criterion is fulfilled if management is mainly exercised by a family;

- the majority of the board is composed of family members.

This multi-criteria definition of the family business is regularly used in the literature (Anderson \& Reeb, 2003; Arrègle et al., 2008; Colot, 2010). Each criterion has the particularity of being easily measured. Indeed, the financial database Belfirst (Note 1) is full of information concerning firms' ownership structure. Moreover, by using each firm's website, ownership information is compared with Belfirst and other information relative to board and management composition are collected. Besides, our definition of the family firm also takes into account the pyramidal structures which are regularly used in family businesses to maintain their control over a firm without owning the majority of its shares (Laporta et al., 1999). Therefore, the use of this selective method determines the real involvement of the family in the firm. 112 family firms have been found by using these criteria. The weak number of family firms identified is mainly due to the opacity regarding the disclosure of ownership structure information since companies frequently use cross-shareholding or holding structure (Gombers et al., 2010).

In order to limit demographic biases related to size and sector, non-family firms have been chosen to ensure a comparability balance in our sample. Indeed, as mentioned by Oogheand Van Wymeersch (2006), financial indicators can be sensitive to economic activities and size. Each non-family firm was thus selected according to the following criteria:

- activity sector: NACEBEL code (Belgian economic activities nomenclature, with 4 figures) identical to family firms;

- size: total assets cannot vary more than $20 \%$ compared to family firms.

By using these other criteria, a sample of 219 family and non-family is collected, separated into 112 family firms and 107 non-family firms.

\subsection{Models}

Our analysis is based on panel data collected on the period 2002-2010 for 219 private firms. The models are built by using Generalised Least Squares (GLS) and Ordinary Least Squares (OLS) regressions. By referring to the literature in this area (Anderson \& Reeb, 2003; Maury, 2006; Chu, 2009), our first equation measures the effect of family ownership on performance and is formulated as follows:

$$
\begin{gathered}
\text { Roa }_{i, t}=\beta_{0}+\beta_{1} \text { crisis }_{t}+\beta_{2} \text { Family }_{i}+\beta_{3} \text { Family }_{i} \text { X } \text { Crisis }_{t}+\beta_{4} \text { Size }_{i, t}+\beta_{5} \text { Age }_{i, t}+\beta_{6} \text { Debts }_{i, t} \\
+\beta_{7} \text { Sales Growth }_{i, t}+\beta_{8} \text { Investment }_{i, t}+\sum_{s=9}^{S} \beta_{s} \text { Sector }_{s}+\varepsilon_{i, t}
\end{gathered}
$$

Dependent variable. Roa $a_{i, t}$ is defined as EBIT of each company $\mathrm{i}$ at time $\mathrm{t}$ divided by total assets of each company $\mathrm{i}$ at time $\mathrm{t}$.

Independent and control variables. Family ${ }_{i, t}$ is a dummy variable taking the value 1 if the company answers our family firm definition, 0 otherwise. Crisis $t_{t}$ is a dummy variable taking the value 1 for the years 2008, 2009 and 2010, 0 otherwise. Size $i, t$ is a control variable for size and approached by the natural logarithm of total asset for each company at time t. $A g e_{i, t}$ is a control variable for the age of the company, since this factor can have an influence on the growth and the survival of the firms. By referring on the methods used by Pieper et al., (2008) and Villalonga and Amit (2006), the age for each company is defined as the natural logarithm of the number of years since its creation. Debts $i, t$ is a variable to control for the effect of capital structure on performance. It is defined as long term debts divided by total asset for each company at time i. Sales Growth ${ }_{i, t}$ is a control variable 
for the growth opportunity. This variable is estimated by the sales growth rate for each firm $\mathrm{i}$ at time. Investment $_{i, t}$ is a control variable to catch investment intensity. It is estimated as capital expenditure divided by sales for each company i at time t. Liquidity ${ }_{i, t}$ is defined as restricted current assets divided by short terms debts for each company i at time t. Sector $r_{s}$ is a dummy variable taking into account the sector affiliation.

\section{Results}

\subsection{Descriptive Statistics}

Means and medians describing the main characteristics of our sample are mentioned in table 1 . It can be stated that family firms significantly outperform non-family firms in terms of sales and ROA $(p<.10$ and $p<.01$ respectively). Family firms are significantly smaller than non-family firms if we refer to total assets and the number of employees $(p<.05)$. Family firms are also significantly older than non-family firms with a difference in mean of more than 3 years and a difference in median of 5 years. Furthermore, family firms surprisingly display higher levels of long-term debts than non-family firms $(\mathrm{p}<.01)$. Concerning investment intensity and liquidity, we can conclude in a significant difference between family and non-family firms.

Table 1. Descriptive statistics

\begin{tabular}{lllllll}
\hline & \multicolumn{2}{l}{ Family firms $(\mathrm{N}=112)$} & \multicolumn{2}{l}{ Non-family firms $(\mathrm{N}=107)$} & \multicolumn{2}{l}{ p-value for differences } \\
\cline { 2 - 7 } & Mean & Median & Mean & Median & Mean & Median \\
\hline ROA & 0.055 & 0.0422 & 0.038 & 0.038 & 0.001 & 0.101 \\
Sales & 84208 & 32206.5 & 74731 & 34764 & 0.074 & 0.012 \\
Total asset & 52792 & 21719.5 & 92181 & 22697 & 0.042 & 0.103 \\
Employees & 332 & 112 & 351 & 173 & 0.041 & 0.017 \\
Age & 33 & 29 & 30 & 24 & 0.000 & 0.000 \\
Liquidity & 1.494 & 1.22 & 1.465 & 1.21 & 0.519 & 0.570 \\
Debts & 0.121 & 0.0762617 & 0.0932633 & 0.025 & 0.000 & 0.000 \\
Invest/Total asset & 0.042 & 0.009 & 0.038 & 0.006 & 0.311 & 0.432 \\
\hline
\end{tabular}

Notes: the two last columns report the two-sided p-values for the difference between family and non-family firms in means and median, respectively. T-tests (Wilcoxon rank tests) are used to test the difference in means (medians).

Table 2. Pearson correlation matrix

\begin{tabular}{|c|c|c|c|c|c|c|c|c|c|c|}
\hline & ROA & Family & Size & Age & Debts & Sales Growth & Invest/Sales & Inv/Tot assets & Liquidity & Crisis \\
\hline ROA & 1 & & & & & & & & & \\
\hline Family & $\begin{array}{l}0.023 * * \\
(0.078)\end{array}$ & 1 & & & & & & & & \\
\hline Size & $\begin{array}{l}0.004 \\
(0.842)\end{array}$ & $\begin{array}{l}-0.038 \\
(0.112)\end{array}$ & 1 & & & & & & & \\
\hline Age & $\begin{array}{l}0.004 \\
(0.863)\end{array}$ & $\begin{array}{l}0.109 * * * \\
(0.000)\end{array}$ & $\begin{array}{l}0.117^{* * * *} \\
(0.000)\end{array}$ & 1 & & & & & & \\
\hline Debts & $\begin{array}{l}-0.204 * * * \\
(0.000)\end{array}$ & $\begin{array}{l}0.098 * * * \\
(0.000)\end{array}$ & $\begin{array}{l}0.156^{* * *} \\
(0.000)\end{array}$ & $\begin{array}{l}-0.131^{* * *} \\
(0.000)\end{array}$ & 1 & & & & & \\
\hline Sales Growth & $\begin{array}{l}-0.007 \\
(0.765)\end{array}$ & $\begin{array}{l}0.024 \\
(0.311)\end{array}$ & $\begin{array}{l}-0.001 \\
(0.988)\end{array}$ & $\begin{array}{l}-0.006 \\
(0.784)\end{array}$ & $\begin{array}{l}0.0349 \\
(0.1447)\end{array}$ & 1 & & & & \\
\hline Invest/Sales & $\begin{array}{l}-0.038 \\
(0.111)\end{array}$ & $\begin{array}{l}0.032 \\
(0.171)\end{array}$ & $\begin{array}{l}0.046 \\
(0.050)\end{array}$ & $\begin{array}{l}-0.030 \\
(0.209)\end{array}$ & $\begin{array}{l}0.1146 * * * \\
(0.0000)\end{array}$ & $\begin{array}{l}-0.004 \\
(0.877)\end{array}$ & 1 & & & \\
\hline Inv/Totassets & $\begin{array}{l}0.100 \\
(0.675)\end{array}$ & $\begin{array}{l}0.032 \\
(0.171)\end{array}$ & $\begin{array}{l}0.007 \\
(0.746)\end{array}$ & $\begin{array}{l}-0.012 \\
(0.597)\end{array}$ & $\begin{array}{l}0.1208 * * * \\
(0.0000)\end{array}$ & $\begin{array}{l}-0.009 \\
(0.713)\end{array}$ & $\begin{array}{l}0.663 * * * \\
(0.000)\end{array}$ & 1 & & \\
\hline Liquidity & $\begin{array}{l}0.240 * * * \\
(0.000)\end{array}$ & $\begin{array}{l}0.010 \\
(0.651)\end{array}$ & $\begin{array}{l}-0.011 \\
(0.632)\end{array}$ & $\begin{array}{l}0.122 * * * \\
(0.000)\end{array}$ & $\begin{array}{l}0.1698 * * * \\
(0.0000)\end{array}$ & $\begin{array}{l}-0.016 \\
(0.495)\end{array}$ & $\begin{array}{l}-0.022 \\
(0.346)\end{array}$ & $\begin{array}{l}-0.014 \\
(0.535)\end{array}$ & 1 & \\
\hline Crisis & $\begin{array}{l}-0.043 * * * \\
(0.0700)\end{array}$ & $\begin{array}{l}0.000 \\
(1)\end{array}$ & $\begin{array}{l}0.126^{* * *} \\
(0.000)\end{array}$ & $\begin{array}{l}0.135 * * * \\
(0.000)\end{array}$ & $\begin{array}{l}0.0033 \\
(0.8902)\end{array}$ & $\begin{array}{l}-0.020 \\
(0.392)\end{array}$ & $\begin{array}{l}-0.043 * * \\
(0.009)\end{array}$ & $\begin{array}{l}-0.068^{* * *} \\
(0.004)\end{array}$ & $\begin{array}{l}0.052 * * \\
(0.029)\end{array}$ & 1 \\
\hline
\end{tabular}

Notes: Family is a dummy variable indicating if the company is considered as a family firm in comparison with our definition given previously. ROA is the Return on Assets. Size is the natural logarithm of total asset. Age is the natural logarithm for the difference between the current date and the date of establishment. Debts corresponds to the long term debts divided by total asset. Sales Growth is the turnover growth rate. Invest/Sales corresponds to investments in PPE, intangible and R\&D divided by sales. Inv/Tot assets corresponds to investments in PPE, intangible and R\&D divided by total asset. Liquidity is defined as the current ratio. Crisis is a crisis indicator. P-values are mentioned within brackets. $*$,**,and $* * *$ indicate statistical significance at respectively $10 \%, 5 \%$, and $1 \%$. 
The analysis of the Pearson correlation matrix confirm the results previously noticed in table 1 regarding economic profitability assessed by ROA. Indeed, ROA is positively correlated with family involvement in the firm $(p<.05)$. A negative correlation is also showed between crisis and performance $(p<.10)$. Investment intensity is also negatively correlated with the outbreak of the financial crisis $(\mathrm{p}<.01$ and $\mathrm{p}<.05$ for Inv/Tot Asset and Inv/Sales respectively). Besides, long term debts present an expected relationship with investment since a positive correlation is observed between debts and investment intensity $(\mathrm{p}<.01)$. Table 2 also confirms the positive relationship between long-term debts and family involvement.

\subsection{Multiple Regression Analysis}

Results in table 3 show that private family firms outperform non-family firms. Moreover, it also indicates that the period of crisis exacerbates the positive relationship between family involvement and performance. Therefore, it can be argued that private family firms have faced the crisis in a more efficient way than their non-family peers. Although these results contradict those of Lins et al., (2011) who focused on listed firms, they are in line with those observed in worldwide conglomerates by Bloch et al., (2012). Accordingly, it seems that private family firms present greater resilience when they face a crisis. Indeed, if we refer to the superior level of sales in private family firms observed in table 1, it seems that private family firms generate their results through their turnover, which seems to confirm the positive influence of maintaining good relationships with customers in order to cope with a period of crisis in a more efficient way even the demand decreases (Bloch et al., 2012).

Table 3. Summary of performance regressions

\begin{tabular}{lllll}
\hline Dependent Variable: ROA & & & & \\
\hline Intercept & $0.158^{* * *}$ & $0.123^{*}$ & $0.1242975^{* * *}$ & $0.121^{* * *}$ \\
& $(0.037)$ & $(0.039)$ & $(0.040)$ & $(0.040)$ \\
Crisis & No & $-0.007^{* *}$ & $-0.007^{* *}$ & -0.004 \\
Family & $0.012^{* *}$ & No & $0.011^{* *}$ & $0.013^{*}$ \\
& $(0.002)$ & & $(0.002)$ & $(0.003)$ \\
Crisis*Family & No & No & No & $0.009^{* *}$ \\
Size & -0.004 & -0.002 & -0.002 & -0.0014 \\
& $(0.003)$ & $(0.003)$ & $(0.003)$ & $(0.003)$ \\
Age & -0.008 & -0.002 & -0.002 & -0.002 \\
& $(0.006)$ & $(0.007)$ & $(0.007)$ & $(0.007)$ \\
Debts & $-0.144 * * *$ & $-0.146^{*}$ & $-0.146^{*}$ & $-0.147^{*}$ \\
& $(0.0181)$ & $(0.018)$ & $(0.0181)$ & $(0.0181)$ \\
Sales growth & 0.000 & 0.000 & 0.000 & 0.000 \\
& $(0.005)$ & $(0.005)$ & $(0.000)$ & $(0.000)$ \\
Invest/Sales & -0.005 & -0.007 & -0.007 & -0.007 \\
& $(0.010)$ & $(0.010)$ & $(0.010)$ & $(0.010$ \\
IndustryDummies & Yes & Yes & Yes & Yes \\
Adj. R ${ }^{2}$ & 0.0627 & 0.0662 & 0.0662 & 0.0665 \\
$\mathrm{~N}$ & 1752 & 1752 & 1752 & 1752 \\
F-test & $86.55^{* * *}$ & $92.58^{* * *}$ & $92.5 * * *$ & $93.46^{* * *}$ \\
\hline
\end{tabular}

Notes: Family is a dummy variable indicating if the company is considered as a family firm in comparison with our definition given previously. ROA is the Return on Assets. Size is the natural logarithm of total asset. Age is the natural logarithm for the difference between the current date and the date of establishment. Debts correspond to the long term debts divided by total asset. Sales Growth is the turnover growth rate. Invest/Sales corresponds to investments in PPE, intangible and R\&D divided by sales. Crisis is a dummy variable taking the value 1 in 2008, 2009 and 2010, 0 otherwise. Standard-errors appear within brackets.*, ${ }^{* *}$, and $* * *$ indicate statistical significance at respectively $10 \%, 5 \%$, and $1 \%$.

\subsection{Robustness Checks}

\subsubsection{Family Ownership Endogeneity?}

Family ownership can be influenced by performance since family shareholders do not want to mobilise resources in firms that present low profitability perspectives. In the case of public firms, Demsetz and Lehn (1985) as well as King and Santor (2008) indicate that the success of the market is only possible by adopting ownership 
structures allowing firms to maximise their value in order to meet the efficiency constraints imposed by the market. Thereby, ownership structures depend on several factors induced by hazards such as economy of scale, regulation and the stability of the environment in which they evolve (Demsetz \& Villalonga, 2001; Maury, 2006). Moreover, Demsetz and Villalonga (2001) also mention that take-overs, compensation plans and insider trading suggest an influence of performance on ownership. Although these last factors are less pregnant in private firms, economy of scale, legal system or environment are several elements which can have an impact on performance and hence on ownership structure. The question is therefore to know if the difference in performance between family and non-family firms is influenced by the potential endogeneity of family ownership (Maury, 2006). In order to take into account this problem of auto-selection or inversed causality, Heckman two-steps method is used. In this model, family control is used as an endogenous variable. The first selection of the probit model includes a variability factor for profitability and performance defined as the sales growth rate and the ROA to meet the restrictions requirements needed for identification. The probit model also contains all control variables used in our performance regressions related in table 3.

Table 4. Control for endogeneity

\begin{tabular}{|c|c|c|c|}
\hline \multicolumn{4}{|l|}{ First-stage regression } \\
\hline & Dependent variable & Familyfirms & \\
\hline & Intercept & 0.4770274 & $(0.267)$ \\
\hline & Roa & $0.1375374 *$ & $(0.740)$ \\
\hline & Crisis & -5.999137 & $(0.970)$ \\
\hline & Family*Crisis & 11.84449 & $(0.958)$ \\
\hline & Size & $-0.1557338^{*}$ & $(0.000)$ \\
\hline & Age & $0.2882499 *$ & $(0.000)$ \\
\hline & Debts & $1.550429^{*}$ & $(0.000)$ \\
\hline & Std sales growth & 0.901234 & $(0.827)$ \\
\hline & Invest/Sales & 0.1896823 & $(0.417)$ \\
\hline \multicolumn{4}{|l|}{ Treatmentregression } \\
\hline & Dependent variable : & $R O A$ & \\
\hline & Intercept & 0.0507057 & $(0.197)$ \\
\hline & Family & $0.0879446^{* * *}$ & $(0.007)$ \\
\hline & Crisis & -0.0382791 & $(0.129)$ \\
\hline & Family*Crisis & $0.0907544 * * *$ & $(0.003)$ \\
\hline & Size & 0.0032009 & $(0.301)$ \\
\hline & Age & $-0.0091107 * * *$ & $(0.087)$ \\
\hline & Debts & $-0.1687191^{*}$ & $(0.000)$ \\
\hline & Sales growth & 0.0000274 & $(0.702)$ \\
\hline & Invest/Sales & -0.0198054 & $(0.417)$ \\
\hline & IndustryDummies & Yes & \\
\hline & $\mathrm{N}$ & 1752 & \\
\hline & Wald $\chi^{2}$ & $161.29^{*}$ & \\
\hline & Heckman's $\lambda$ & $-0.0546357 * * *$ & \\
\hline
\end{tabular}

Notes: Family is a dummy variable indicating if the company is considered as a family firm in comparison with our definition given previously. ROA is the Return on Assets. Size is the natural logarithm of total asset. Age is the natural logarithm for the difference between the current date and the date of establishment. Debts corresponds to the long term debts divided by total asset. Sales Growth is the turnover growth rate. Std sales growth corresponds to the standard-error of the sales growth rate for 8 years. Invest/Sales corresponds to investments in PPE, intangible and R\&D divided by sales. Crisis is a dummy variable taking the value 1 in 2008, 2009 and 2010, 0 otherwise. P-values appear within brackets. ${ }^{*}, *$, and $* * *$ indicate statistical significance at respectively $10 \%, 5 \%$, and $1 \%$.

Table 4 shows that family involvement is positively linked with ROA $(\mathrm{p}<.10)$. The second regression presents a positive relationship between family involvement and performance $(\mathrm{p}<.01)$. At the same time, a positive relationship is found between the interaction terms Family*Crisis $(\mathrm{p}<.01)$, which confirm that the crisis reinforce the positive relationship between family involvement and performance in private firms. Besides, Heckman's statistic is significant, indicating that our results are unbiased. These results confirm those obtained in table 3, and thus the outperformance of private family firms with an exacerbation of this positive relationship during the period of crisis. 


\subsubsection{Multicolinearity Problem?}

To ensure that multicolinearity is not a problem in our regression, variance inflation factors (VIF) are calculated. Our results mentioned in table 6 indicate that the multicolinearity problem is mitigated in our models since the VIF are lower than the critical value of 5 (Hair et al., 2010).

Table 5. Summary of Variance Inflation Factors (VIF)

\begin{tabular}{lll}
\hline Performance regression & & VIF \\
\hline Variables & Size & 2.68 \\
& Age & 2.59 \\
& Crisis & 3.32 \\
& Family & 3.31 \\
& Family*Crisis & 3.25 \\
& Debts & 1.7 \\
& Invest/sales & 1.07 \\
& Sales growth & 1 \\
\hline
\end{tabular}

Notes: Variance inflation factors are named VIF in the table.

\section{Conclusion}

The presence of family firms in the economic fabric all around the world is a field of great interest in the literature. A recurrent theme is to understand if that kind of company outperforms other types of firms. Nevertheless, most of the research focuses on public firms (Astrachan, 2010) since the data regarding ownership, governance and management structures are less accessible for private firms. This paper contributes to the literature on this point by investigating the field of private family firms. Moreover, although numerous research analyse the relationship between family involvement and performance, most of them have been carried out without taking into account environment modifications such as the financial and economic crisis context (Bloch et al., 2012). The perturbations which still hit financial an economic crisis provides an opportunity for researchers specialised in family business. This paper also contributes to the literature on that point. Furthermore, this article also considers endogeneity problems by using Heckman two-steps method in order to make the results more robust. This methodological aspect is important to be underlined since numerous studies do not integrate the endogenous character of ownership (Maury, 2006).

A first-step analysis of our results shows a positive relationship between family involvement and performance independently from the crisis. These results corroborate previous findings related to publicly-traded firms (Anderson \& Reeb, 2003; Maury, 2006). Moreover, this research also indicates that the crisis positively moderates the relationship between family involvement and performance in private firms. Whereas previous research has underlined a negative effect of family influence in public firms during periods of crisis (Lemmon \& Lins, 2003; Lins et al., 2011), our results confirm the greater potential of resilience that can be induced by family involvement in the organisation (Bloch et al., 2012). Indeed, family involvement seems to enhance flexibility through less formalism and procedures (Carney, 2005), thus improving their ability to innovatively face unexpected events. Moreover, the importance given to socioemotional wealth during stable periods (Gomez-Mejia et al., 2007) seems to provide private family firms with a competitive advantage when they have to cope with sudden shocks. Indeed, our results suggest that the vector of performance in private family firms is sales which can be stimulated by the loyalty of their customers in a context of crisis. Therefore, it seems that family involvement positively contributes to value creation through a perpetual concern for preserving socioemotional endowment of family principals (Gomez-Mejia et al., 2007; Berrone et al., 2012) and a less formalistic view of the organisation (Carney, 2005), so that resilience can be fostered during periods of crisis.

Several limits and reflexions must be underlined in this paper. The completeness of our sample is not ensured since it only contains 219 firms. Although this situation is due to the opacity surrounding ownership and organisational structures in private firms, this research would deserve to be considered on a larger sample. The realisation of a survey with questionnaires could allow us to obtain more information and to improve the robustness of our results. In that way, the effect of corporate governance mechanisms on performance in private firms during the crisis could also be analysed in a comparative logic between family and non-family firms, but also between family firms themselves so that we could take into account the heterogeneity of these organisations for which this field is under-investigated (Astrachan, 2010). Another point of reflexion is about the methodology employed because it can have an effect on the results obtained (Block et al., 2011). In that respect, Block et al. 
(2011) and Mazzi (2011) indicate a very useful and relevant statistical method in order to catch the relationship between family ownership and performance, namely a Bayesian approach. The use of that method improves the accuracy regarding the acceptation degree of the null hypothesis. Moreover, it also reduces a bias in the literature which systematically rejects the results for which the significance threshold is higher than $5 \%$ (Block et al., 2011). Finally, in order to be generalised, our results have to be confirmed on other markets with specific cultural (Hofstede, 2001) or legal (Laporta et al., 1999) characteristics.

\section{References}

Ahmad, A. J., \& Amran, N. Z. (2010). Corporate Governance mechanisms and performance: Analysis of Malaysian family and non-family controlled companies. Journal of Modern Accounting and Auditing, 6(2), $1-15$.

Allouche, J., \& Amann, B. (1998). La confiance: une explication des performances des entreprises familiales. Revue EconomieetSociété, 8(9), 129-154.

Anderson, R., \& Reeb, D. (2003). Founding family ownership and firm performance: evidence from the S\&P 500. The Journal of Finance, 58(3), 1301-1327. http://dx.doi.org/10.1111/1540-6261.00567

Andres, C. (2008). Large shareholders and firm performance-An empirical examination of founding-family ownership. Journal of Corporate Finance, 14(4), 431-445. http://dx.doi.org/10.1016/j.jcorpfin.2008.05.003

Arrègle, J. L., Hitt, M., Sirmon, D., \& Very, P. (2007). The development of organizational social capital: Attributes of Family Firms. Journal of Management Studies, 44(1), 73-95. http://dx.doi.org/10.1111/j.1467-6486.2007.00665.x

Arrègle, J. L., Sirmon, D. G., Hitt, M. A., \& Webb, J. W. (2008). The Role of Family Influence in Firms' Strategic Responses to Threat of Imitation. Entrepreneurship Theory and Practice, 32(6), 979-998. http://dx.doi.org/10.1111/j.1540-6520.2008.00267.x

Astrachan, J. H. (2010). Strategy in family business: Toward a multidimensional research agenda. Journal of Family Business Strategy, 1(1), 6-14. http://dx.doi.org/10.1016/j.jfbs.2010.02.001

Barth, E., Gulbrandsen, T., \& Schone, P. (2005). Family Ownership and Productivity: the role of $\begin{array}{lllll}\text { Owner-management. Journal of Corporate } & \text { Finance, 11(1-2), 107-127. }\end{array}$ http://dx.doi.org/10.1016/j.jcorpfin.2004.02.001

Bégin, L., \& Chabaud, D. (2010). La résilience des organisations. Revue française de gestion, 200, 127-142. http://dx.doi.org/10.3166/rfg.200.127-142

Berrone, P., Cruz, C., \& Gomez-Mejia, L. R. (2012). Socioemotional Wealth in Family Firms Theoretical Dimensions, Assessment Approaches, and Agenda for Future Research. Family Business Review, 25(3), 258-279. http://dx.doi.org/10.1177/0894486511435355

Bloch, A., Kachaner, N., \& Mignon, S. (2012). La stratégie du propriétaire: Enquête sur la résilience des entreprises familiales face à la crise. Paris: Editions Pearson.

Block, H. B., Jaskiewicz, P., \& Miller, D. (2011). Ownership versus management effects on performance in family and founder companies: A Bayesian reconciliation. Journal of Family Business Strategy, 2(4), 232-245. http://dx.doi.org/10.1016/j.jfbs.2011.10.001

Bughin, C., \& Colot, O. (2008). La performance des PME familiales belges: une étude empirique. Revue française de gestion, 34, 1-17. http://dx.doi.org/10.3166/rfg.186.1-17

Carney, M. (2005). Corporate governance and competitive advantage in family-controlled firms. Entrepreneurship Theory and Practice, 19(3), 249-265. http://dx.doi.org/10.1111/j.1540-6520.2005.00081.x

Charreaux, G. (1991). Structure de propriété, relation d'agence et performance financière. Revue économique, $42,521-552$.

Chen, L., \& Lu, L. (2009). Family Firms, Corporate Governance and Performance: evidence from Zhejiang. Paper prepared for the conference: US-China Business Cooperation in the 21st Century: Opportunities and Challenges for Entrepreneurs. Indiana University, Indianapolis and Bloomington, Indiana, April 15-17, 2009.

Chen, S., Chen, X., Cheng, Q., \& Shevlin, T. (2010). Are family firms more tax aggressive than non-family firms? Journal of Financial Economics, 95, 41-61. http://dx.doi.org/10.1016/j.jfineco.2009.02.003

Chrisman, J. J., Chua, J. H., \& Litz, R. A. (2004). Comparing the agency cost of family and nonfamily firms. 
Entrepreneurship Theory and Practice, 28, 335-354. http://dx.doi.org/10.1111/j.1540-6520.2004.00049.x

Chrisman, J. J., Chua, J. H., \& Steier. (2011). Resilience of family firms: An introduction. Entrepreneurship Theory and Practice, 35(6), 1107-1118. http://dx.doi.org/10.1111/j.1540-6520.2011.00493.x

Chu, W. (2009). Family ownership and firm performance: Influence of family management, family control, and firm size. Asian Pacific Journal of management.

Chua, J. H., Chrisman, J. J., \& Sharma, P. (1999). Defining family business by behavior. Entrepreneurship Theory and Practice, 23(4), 19-39.

Coleman, S., \& Carsky, M. (1999). Sources of capital for small family-owned business: evidence from the National Survey of Small Business Finances. Family Business Review, 12(1), 73-85. http://dx.doi.org/10.1111/j.1741-6248.1999.00073.x

Davis, J. H., Schoorman, F. D., \& Donaldson, L. (1997). Toward a stewardship theory of management. Academy of Management Review, 22, 20-47.

Demsetz, H. (1983). The Structure of Ownership and the Theory of the Firms. Journal of Law and Economics, 26, 375-390. http://dx.doi.org/10.1086/467041

Demsetz, H., \& Lehn, K. (1985). The structure of corporate ownership: causes and consequences. Journal of Political Economy, 93, 1155-1177. http://dx.doi.org/10.1086/261354

Demsetz, H., \& Villalonga, B. (2001). Ownership structure and corporate performance. Journal of Corporate Finance, 7, 209-233. http://dx.doi.org/10.1016/S0929-1199(01)00020-7

Duh, M., Tominc, P., \& Rebernik, M. (2009). The Importance of Family Enterprises in Transition Economies: Is $\begin{array}{llll}\text { It Overestimated? Eastern } & \text { European }\end{array}$ http://dx.doi.org/10.2753/EEE0012-8775470602

Gabrié, H. (2008). Existe-t-il une structure optimale de la propriété des firmes en terme de profit? Revue d'Économie Financière, 91, 191-229. http://dx.doi.org/10.3406/ecofi.2008.5066

Giovannini, R. (2010). Corporate governance, family ownership and performance. Journal of Management and Governance, 14(2), 145-166. http://dx.doi.org/10.1007/s10997-009-9093-x

Gombers, P. A., Ishii, J., \& Metrick, A. (2010). Extreme Governance: An analysis of dual-class firms in the United States. The Review of Financial Studies, 23(3), 1051-1088. http://dx.doi.org/10.1093/rfs/hhp024

Gomez-Mejia, L. R., Haynes, K. T., Nunez-Nickel, M., Jacobson, K. J. L., \& Moyano-Fuentes, J. (2007). Socioemotional wealth and business risk in family-controlled firms: Evidence from Spanish olive oil mills. Administrative Science Quarterly, 52(1), 106-137.

Hair, J. F., Black, B., Babin, B., \& Anderson, R. E. (2010). Multivariate data analysis (6th ed.). Upper Saddle River, NJ: Prentice Hall.

Hertzel, M., \& Smith, R. L. (1993). Market Discounts and Shareholder Gains for Placing Equity Privately. Journal of Finance, 48, 459-485. http://dx.doi.org/10.1111/j.1540-6261.1993.tb04723.x

Hofstede, G. (2001). Cultures consequences: Comparing values, behavior, institutions, and organizations across nations (2nd ed.). Thousand Oaks: Sage Publications.

Ifera. (2003). Family business dominate. Family Business Review, 26(4), 235-239.

James, H. (2006). Family Capitalism. Cambridge, MA: Belknap-Harvard University Press.

Jaskiewicz, P., Gonzalez, V. M., Menendes, S., \& Schiereck, D. (2005). Long-run IPO performance analysis of German and Spanish family-owned businesses. Family Business Review, 18, 179-202. http://dx.doi.org/10.1111/j.1741-6248.2005.00041.x

Jensen, M. C., \& Meckling, W. F. (1976). Theory of the firm managerial behavior, agency cost, and ownership $\begin{array}{lllll}\text { structure. Journal of } & \text { Financial 305-360. }\end{array}$ http://dx.doi.org/10.1016/0304-405X(76)90026-X

Kenyon-Rouvinez, D., \& Ward, J. L. (2004). Les entreprises familiales. Paris: Presse Universitaire de France.

Khanna, T., \& Palepu, K. (2000). Is Group Affiliation Profitable in Emerging Markets? An Analysis of Diversified Indian Business Groups. Journal of Finance, 55, 867-891. http://dx.doi.org/10.1111/0022-1082.00229

King, M. R., \& Santor, E. (2008). Family values: Ownership Structure, Performance and Capital Structure of 
Canadian firms. Journal of Banking \& Finance, 32(11), 2423-2432. http://dx.doi.org/10.1016/j.jbankfin.2008.02.002

Klein, P., Shapiro, D., \& Young, J. (2005). Corporate Governance, Family Ownership and Firm Value: the Canadian Evidence. Corporate Governance: An International Review, 13(6), 769-784. http://dx.doi.org/10.1111/j.1467-8683.2005.00469.x

Kowalewski, O., Talavera, O., \& Stetsyuk, I. (2010). Influence of family involvement in management and ownership on firm performance: Evidence from Poland. Family Business Review, 23(1), 45-59. http://dx.doi.org/10.1177/0894486509355803

La Porta, R., Lopez-de-Silanes, R., \& Shleifer, A. (1999). Corporate ownership around the world. Journal of Finance, 54(2), 471-517. http://dx.doi.org/10.1111/0022-1082.00115

Lemmon, M. L., \& Lins, K. V. (2003). Ownership structure, corporate governance, and firm value: Evidence from the East Asian financial crisis. The journal of finance, 58(4), 1445-1468. http://dx.doi.org/10.1111/1540-6261.00573

Lins, K. V., Volpin, P., \& Wagner, H. F. (2011). The value of controlling blockholders during the global financial crisis. Working paper.

Lubatkin, M., Schulze, W., Ling, Y., \& Dino, R. (2005). The effects of parental altruism on the governance of family-managed firms. Journal of Organizational Behavior, 26, 313-330. http://dx.doi.org/10.1002/job.307

Martikainen, M., Nikkinen, J., \& Vahamaa, S. (2009). Production functions and productivity of family firms: Evidence from the S\&P 500. The Quarterly Review of Economics and Finance, 49(2), 295-307. http://dx.doi.org/10.1016/j.qref.2007.11.001

Maury, B. (2006). Family ownership and firm performance: empirical evidence from Western European $\begin{array}{llll}\text { corporations. Journal of } & \text { Corporate }\end{array}$ http://dx.doi.org/10.1016/j.jcorpfin.2005.02.002

Mazzi, C. (2011). Family business and financial performance: current state of knowledge and future research challenges. Journal of Family Business Strategy, 2(3), 166-181. http://dx.doi.org/10.1016/j.jfbs.2011.07.001

Miller, D., \& Le Breton-Miller, I. (2005). Managing for the Long Run. Boston, MA: Harvard Business School Press.

Pearson, A., Carr, J. C., \& Shaw, J. (2008). Clarifying the familiness construct: a social capital perspective. Entrepreneurship Theory and Practice, 32, 949-969. http://dx.doi.org/10.1111/j.1540-6520.2008.00265.x

Pieper, T. M. (2007). Mechanisms to assure long-term family business survival: A study of the dynamics of cohesion in multigenerational family business families. European University Studies: Series 5, 3285, 310.

Pieper, T. M., Klein, S., \& Jaskiewics, P. (2008). The impact of goal alignment on board existence and top management team compensation: Evidence from family-influenced businesses. Journal of Small business Management, 46, 372-394. http://dx.doi.org/10.1111/j.1540-627X.2008.00249.x

Pruit, B. (1999). Timken: From Missouri to Mars - A century of leadership in manufacturing. Boston, MA: Harvard Business School Press.

Rutherford, M. W., Kuratko, D. F., \& Holt, D. T. (2008). Examining the Link Between "Familiness" and Performance: Can the F-PEC Untangle the Family Business Theory Jungle? Entrepreneurship Theory and Practice, 32, 1089-1109. http://dx.doi.org/10.1111/j.1540-6520.2008.00275.x

Shleifer, A., \& Vishny, W. (1997). A survey of corporate governance. The Journal of Finance, 52(2), 737-783. http://dx.doi.org/10.1111/j.1540-6261.1997.tb04820.x

Sraer, D., \& Thesmar, D. (2007). Performance and behavior of family firms: evidence from the French stock market. Journal of the European Economic Association, 5(4), 709-751. http://dx.doi.org/10.1162/JEEA.2007.5.4.709

Steijvers, T., \& Niskanen, M. (2011). Tax Aggressive Behaviour in Private Family Firms - the effect of the CEO and board of directors. Proceedings of the 7th European Conference on Management, Leadership and Governance, 379-386.

Stein, J. C. (1997). Internal Capital Markets and the Competition for Corporate Resources. Journal of Finance, 52, 111-133. http://dx.doi.org/10.1111/j.1540-6261.1997.tb03810.x

Villalonga, B., \& Amit, R. (2006). How do family ownership, control and management affect firm value? 
Journal of Financial Economics, 80(2), 385-417. http://dx.doi.org/10.1016/j.jfineco.2004.12.005

Villalonga, B., \& Amit, R. (2010). Family Control of firms and industries. Financial Management, 39(3), 863-904. http://dx.doi.org/10.1111/j.1755-053X.2010.01098.x

Ward, J. (2004). Perpetuating the family business: 50 lessons learned from long lasting successful families in business. Marietta, GA: Family Enterprise Publishers. http://dx.doi.org/10.1057/9780230505995

Weick, K. E., \& Roberts, K. H. (1993). Collective Mind in Organizations: Heedful Interrelating on Flight Decks. Administrative Science Quarterly, 38, 357-381. http://dx.doi.org/10.2307/2393372

Weick, K. E., \& Sutcliffe, K. M. (2007). Managing the Unexpected: Resilient Performance in and Age of Uncertainty (2nd ed.). San Francisco, CA: Jossey-Bass.

Wruck, K. H. (1989). Equity Ownership Concentration and Firm Value: Evidence from Private Equity Financings. Journal of Financial Economics, 23, 3-28. http://dx.doi.org/10.1016/0304-405X(89)90003-2

Yurtoglu, B. (2000). Ownership, Control and Performance of Turkish listed Firms. Empirica, 27(2), 193-222. http://dx.doi.org/10.1023/A:1026557203261

Zahra, S., Rawhouser, H., Bhawe, N., Neubaum, D., \& Hayton, J. (2008). Globalization of social entrepreneurial opportunities. Strategic Entrepreneurship Journal, 2, 117-131. http://dx.doi.org/10.1002/sej.43

Zhou, H. (2012). Are Family Firms Better Performers During Financial Crisis? Working paper.

Note

Note 1. Belfirst contains all annual financial statements of Belgian firms which are subject to the legal obligation to publish them at the National Bank of Belgium.

\section{Copyrights}

Copyright for this article is retained by the author(s), with first publication rights granted to the journal.

This is an open-access article distributed under the terms and conditions of the Creative Commons Attribution license (http://creativecommons.org/licenses/by/3.0/). 